\title{
Aberrant Hepatic MicroRNA Expression in Nonalcoholic Fatty Liver Disease
}

\author{
Yue Ying Feng ${ }^{a, b}$ Xiao Qin Xü Chen Bo Jic Chun Mei Shic Xi Rong Guo ${ }^{c}$ \\ Jun Fen Fu
}

aDepartment of Endocrinology, the Children's Hospital of Zhejiang University School of Medicine, Hangzhou; ${ }^{\text {bC }}$ urrent affiliation: Department of Endocrinology, Ningbo Women and Children's Hospital, Ningbo; 'Department of Pediatrics, Nanjing Maternity and Child Health Hospital of Nanjing Medical University, Jiangsu Province, Nanjing, China

\section{Key Words}

NAFLD $・$ miRNA $・$ Human hepatocyte $\cdot$ HepG2 cells $•$ Deep sequencing

\begin{abstract}
Background/Aim: Emerging evidence suggests that microRNA (miRNA) mediated gene regulation influences the maintenance of metabolic homeostasis, particularly the states of obesity and insulin resistance, thereby providing a potential link between miRNAs and nonalcoholic fatty liver disease (NAFLD). Methods: Sprague-Dawley rats fed a high-fat diet (HFD) were used to establish a rat model of NAFLD. The miRNA expression profile of liver tissues was evaluated using Illumina HiSeq deep sequencing. Selected miRNAs were then validated by real-time PCR at both 4- and 12-week time points. Furthermore, the expression levels of these miRNAs were assessed in HepG2 cells and human hepatocytes treated with free fatty acids (FFAs) and proinflammatory factors (tumour necrosis factor-alpha (TNF- $\alpha$ ) and interleukin-6 (IL-6). Results: Our results showed that consumption of a HFD for 4 weeks caused simple steatosis, which progressed to steatohepatitis at 12 weeks. miRNA deep sequencing analysis identified 44 known up-regulated miRNAs (fold change $>1.5$ ) and 12 down-regulated miRNAs (fold change $<0.5$ ). Among the abnormally expressed miRNAs, miR200a, miR-200b, miR-200c, miR-146a, miR-146b and miR-152 were up-regulated both in vitro and vivo. Interestingly, the expression levels of these six miRNAs were increased in HepG2 cells and human hepatocytes after treatment with FFAs and proinflammatory factors. Conclusion: These findings suggest a critical role for miRNAs in the pathogenesis of NAFLD.
\end{abstract}

Y. Y. Feng and X. Q. Xu authors contributed equally to this work. 


\section{Introduction}

Nonalcoholic fatty liver disease (NAFLD) is defined as the pathological accumulation of lipids in hepatocytes without significant alcohol consumption, use of steatogenic medication or hereditary disorders [1]. The pathologic classification of NAFLD encompasses isolated hepatic steatosis, nonalcoholic steatohepatitis (NASH) and cryptogenic fibrosis/cirrhosis [2]. As the global obesity epidemic grows, the incidence of NAFLD is increasing; in morbidly obese adults, the prevalence of NAFLD is more than $90 \%$ [3], and the prevalence is thought to reach up to $50 \%$ in obese children [4]. Unfortunately, patients with NAFLD show increased rates of overall mortality compared to matched control populations [5, 6]. Although much progress has been made towards gaining a better understanding of the pathogenesis of NAFLD, the exact molecular mechanisms remain unclear.

MicroRNAs (miRNAs), which are 19-25-nucleotide (nt) non-coding small RNAs, modulate gene expression by binding to the 3' untranslated region (3'UTR) of target messenger RNAs (mRNAs). MiRNAs are thought to be involved in various biological and pathological processes, including the growth and development of organisms, cancer and other diseases [7-10]. Recent research has demonstrated that miRNAs are able to regulate metabolismrelated genes that may be involved in the pathogenesis of NAFLD. For example, miR-122 is the most highly expressed miRNA in the liver and can regulate cholesterol and fatty acid metabolism $[11,12]$, and $\mathrm{miR}-10 \mathrm{~b}$ has been shown to regulate the level of cellular steatosis through peroxisome proliferator-activated receptor-alpha [13]. In addition, several other miRNAs have been shown to regulate insulin resistance [14], mitochondrial dysfunction [15], oxidative stress [16], and inflammation [17], which are all generally regarded as critical components of NAFLD.

Therefore, we hypothesised that certain miRNAs may regulate steatosis in NAFLD. In the present study, we employed the Illumina HiSeq deep sequencing platform to screen the miRNA expression profiles in high-fat diet (HFD)-induced fatty liver tissue and control tissue from animals fed a standard diet. From our sequencing results, we identified differentially expressed miRNAs between the normal control group and the model group. We then investigated the expression of certain miRNAs in HepG 2 cells and human hepatocytes cultured with a high concentration of free fatty acids (FFAs) with or without proinflammatory factors. We found that miR-200a, miR-200b, miR-200c, miR-146a, miR-146b and miR-152 were upregulated both in fatty liver tissues and in cells cultured with FFAs and proinflammatory factors.

\section{Materials and Methods}

\section{Animal experiments}

This study was approved by the University Committee for the Ethical Care and Use of Animals in Experiments of ZheJiang University (Permit Number: 20100022). Forty male Sprague-Dawley rats were obtained from the Experimental Animal Center of Nanjing Medical University (Nanjing, China). The animals were divided randomly into the following four groups, with each group matched for body weight and age: (1) normal control group A ( $n=10)$ and (2) normal control group B $(n=10)$, which were fed a standard diet for 4 and 12 weeks, respectively; and (3) model group C ( $n=10)$ and (4) model group $D(n=10)$, which were fed a HFD (standard diet $+10 \%$ lard $+2 \%$ cholesterol) for 4 and 12 weeks, respectively. All of the animals were given ad libitum access to food and purified water and were housed in sterilised cages with a 12-h light/dark cycle. At the end of week 4 or 12, after one night of fasting, the rats were weighed, and blood samples were collected through the inferior vena cava under general anaesthesia using $10 \%$ chloral hydrate inhalation. Intact livers were removed from the abdominal cavity and washed with ice-cold $0.9 \%$ saline. The weights of the livers were measured, and the hepatic index was calculated (wet weight of liver/body weight). The right lobes of the livers were dissected, and pieces were frozen immediately in liquid nitrogen and stored at $-80^{\circ} \mathrm{C}$ for further analysis. The left lobes were soaked in $4 \%$ paraformaldehyde for histological observation by haematoxylin and eosin (H\&E) staining. 


\begin{tabular}{|c|c|c|}
\hline Cellular Physiology & Cell Physiol Biochem 2014;34:1983-1997 & \\
\hline and Biochemistry & $\begin{array}{l}\text { DoI: 10.1159/000366394 } \\
\text { Published online: November 26, } 2014\end{array}$ & $\begin{array}{l}\text { O 2014 S. Karger AG, Basel } \\
\text { www.karger.com/cpb }\end{array}$ \\
\hline
\end{tabular}

The diagnosis of NASH and classification of severity were made according to the 2008 criteria of the Chinese Medical Association Committee of Nonalcoholic Fatty Liver Disease [18].

\section{Serum biochemical analysis}

The levels of serum alanine aminotransferase (ALT), aspartate aminotransferase (AST), total cholesterol (TC) and triglycerides (TG) were determined using a fully automatic biochemical analyser (Roche Inc., USA). Hepatic TG levels were assayed using a TG assay kit (Applygen Technologies Inc., Beijing, China).

\section{Deep sequencing}

Total RNA from the livers of normal control group B and model group D rats was obtained using the Trizol (Invitrogen) reagent. Subsequently, small RNAs ranging from 18 to $30 \mathrm{nt}$ were isolated using denaturing polyacrylamide gel electrophoresis. We then ligated synthetic oligonucleotide adapters of known sequences to the 3' and 5' ends of the small RNA pool using T4 RNA ligases, which can introduce primer-binding sites for reverse transcription and PCR amplification. Then, the modified small RNAs were reversed transcribed into cDNA and amplified by PCR. Thereafter, purified samples were obtained for sequencing-by-synthesis (Solexa). Mireap software (http://sourceforge.net/projects/mireap/) was used to identify both known and novel microRNAs from small RNA libraries that were deep-sequenced using Solexa technology. Finally, differentially expressed microRNAs with statistical significance were identified through volcano plot filtering. The threshold used to screen up-regulated and down-regulated microRNAs was a 1.5 -fold increase and a 0.5 -fold decrease, respectively $(P<0.05)$.

\section{Cell culture}

Human hepatocellular carcinoma cells (HepG2) were purchased from ATCC (Rockville, MD, USA), and human hepatocytes were obtained from Sciencell. HepG2 cells were cultured in Dulbecco's modified Eagle's medium (DMEM) (Gibco) supplemented with 10\% heat-inactivated foetal bovine serum (FBS), 100 $\mathrm{U} / \mathrm{ml}$ penicillin, and $100 \mu \mathrm{g} / \mathrm{ml}$ streptomycin at $37^{\circ} \mathrm{C}$ and $5 \% \mathrm{CO}$. Human hepatocytes were cultured in hepatocyte medium (Sciencell) containing 5\% FBS, $10 \mu \mathrm{g} / \mathrm{ml}$ bovine serum albumin (BSA), $10 \mu \mathrm{g} / \mathrm{ml}$ apotransferrin, $5 \mu \mathrm{g} / \mathrm{ml}$ insulin, $2 \mathrm{ng} / \mathrm{ml}$ epidermal growth factor (EGF), $2 \mathrm{ng} / \mathrm{ml}$ fibroblast growth factor-2 (FGF-2), $2 \mathrm{ng} / \mathrm{ml}$ insulin-like growth factor-1 (IGF-1), $0.7 \mathrm{nM}$ retinoic acid, and $1 \mu \mathrm{g} / \mathrm{ml}$ hydrocortisone. The cultures were used at $60-80 \%$ confluency.

\section{Lipid accumulation and Oil Red $O$ stain}

To induce fat overloading of cells, human hepatocytes and HepG2 cells at $80 \%$ confluency were cultured for $24 \mathrm{~h}$ in complete medium containing $1 \mathrm{mM}$ long-chain mixed FFAs (oleate acid and palmitate (SigmaAldrich) mixed at a final ratio of 2:1 and bound to $1 \%$ defatted BSA (Equitech-Bio) [19]. To detect lipid droplet accumulation, cells were stained with Oil Red O. Briefly, cells were rinsed three times in PBS, fixed in $4 \%$ paraformaldehyde, rinsed three times in PBS, stained with $0.3 \%$ Oil Red 0 for $30 \mathrm{~min}$ at $37^{\circ} \mathrm{C}$, rinsed with PBS and photographed. Then integrated option density (IOD) determined by Image Pro-Plus according to the staining intensity by visual assessment was utilized to compare the lipid droplet accumulation. To quantify lipid accumulation, cultured cells with or without 1mM FFAs were scraped in PBS and disrupted by cell lysis buffer. The intracellular triglycerides were assayed using a commercial kit (GPO-POD; Applygen Technologies Inc., Beijing, China) according to the manufacturer's recommended protocol.

\section{Proinflammatory factor assay}

Inflammation is an important component of NAFLD. Specifically, tumour necrosis factor-alpha (TNF- $\alpha$ ) and interleukin-6 (IL-6) are known to be significantly increased in NAFLD patients compared to healthy controls $[3,20]$. To assess the effect of proinflammatory cytokines on the expression of miRNAs, we used recombinant human IL- 6 and TNF- $\alpha$ (R\&D Systems, Minneapolis, MN, USA) to treat HepG2 cells. Specifically, cells were seeded in normal growth medium at 60,000 cells $/ \mathrm{ml}$, with $2.0 \mathrm{ml} /$ well in 6 -well culture plates, and grown for 2 days. On day 3, the cells were washed with serum-free DMEM and then incubated in serumfree DMEM for an additional $24 \mathrm{~h}$. Subsequently, the cells were washed and then incubated with DMEM containing $10 \mathrm{ng} / \mathrm{ml} \mathrm{TNF-} \alpha$ [21], $25 \mathrm{ng} / \mathrm{ml} \mathrm{IL-6} \mathrm{[22],} \mathrm{or} \mathrm{both} \mathrm{of} \mathrm{these} \mathrm{compounds} \mathrm{for} 0,4,8$ or $24 \mathrm{~h}$. All of the cell experiments were performed in triplicate. 


\section{Quantitative miRNA expression analysis}

Total RNA was extracted from $10 \mathrm{mg}$ of liver tissue using a miRNeasy mini kit (Qiagen, Valencia, CA, USA), according to the manufacturer's instructions. Briefly, the tissue was dispersed using an electric homogeniser after adding Qiazol lysis reagent, and the cells were directly lysed using Qiazol lysis reagent. Then, chloroform was added, and the RNA phase was transferred to a column. After washing with the provided buffer, the RNA was dissolved in nuclease-free water. The RNA was quantified using a NanoDrop spectrophotometer (Thermo Scientific, USA), and the purity was evaluated by measuring the A260/280 ratio.

The reverse transcriptase (RT) primer, PCR primers, and TaqMan probe for miR-200a, miR-200b, miR-200c, miR-146a, miR-146b and miR-152 were purchased from Applied Biosystems (Foster City, CA, USA). Total RNA was reverse-transcribed using the TaqMan MicroRNA reverse transcription kit (Applied Biosystems). U6 snRNA served as an endogenous control for miRNA expression. Reverse transcription was performed in a thermal cycler using the following reaction protocol: $30 \mathrm{~min}$ at $16^{\circ} \mathrm{C}$ (annealing), $30 \mathrm{~min}$ at $42^{\circ} \mathrm{C}$ (cDNA synthesis), and $5 \mathrm{~min}$ at $85^{\circ} \mathrm{C}$ (enzyme denaturation). For real-time PCR, $10 \mu \mathrm{l}$ of TaqMan $2 \times$ Universal PCR Master Mix II, $1 \mu \mathrm{l}$ of cDNA, $1 \mu \mathrm{l}$ of the TaqMan miRNA assay mix (Applied Biosystems), and 8 $\mu \mathrm{l}$ of water were mixed for $10 \mathrm{~min}$ at $95^{\circ} \mathrm{C}$, followed by 40 cycles of $15 \mathrm{sec}$ at $95^{\circ} \mathrm{C}$ and $1 \mathrm{~min}$ at $60^{\circ} \mathrm{C}$. An ABI 7500 real-time PCR system (Applied Biosystems) was used for the real-time PCR experiments. Data analysis was carried out using the $2-\Delta \mathrm{Ct}$ Method. Difference in the Ct between miRNA and U6 was called $\Delta \mathrm{Ct}$. Data are $2-\Delta \mathrm{Ct}$ levels calculated relative to the U6 snRNA expression.

\section{Bioinformatic analysis}

Predicted gene targets of all differentially expressed miRNAs were obtained using two computer-aided algorithms, including TargetScan (http://www.targetscan.org/) and miRanda (http://www.microrna.org/). To further understand the function, classification and metabolic regulatory networks of the miRNA targets, functional analyses were performed based on the Gene Ontology (GO) database (http://www.geneontology. org/) and the Kyoto Encyclopedia of Genes and Genomes (KEGG) pathway database (http://www.genome. $\mathrm{jp} / \mathrm{kegg} /$ ). The GO database is extensively used to analyse all types of high-throughput experiments, such as large-scale sequencing efforts [23], microarrays [24] protein-protein interactions [25], protein-DNA interactions [26], and knockouts [27]. The KEGG pathway is a collection of manually drawn pathway maps representing molecular interactions and reaction networks and has been widely used for biological interpretation of higher-level systemic functions [28].

\section{Statistical analysis}

All of the data are presented as the mean \pm standard deviation. The statistical significance between two groups was compared using the Student's t-test, and one-way analysis of variance (ANOVA) was used for comparisons of more than three groups. A $P$ value $<0.05$ was considered statistically significant.

\section{Results}

\section{Analysis of the animal model}

Twenty male Sprague-Dawley rats were fed a HFD (standard diet $+10 \%$ lard $+2 \%$ cholesterol) for 4 or 12 weeks. All of the rats developed NASH at the end of 12 weeks according to the criteria for NASH diagnosis. Histological examinations showed normal liver tissue or mild microvesicular steatosis without inflammatory infiltration or fibrosis in the normal group (Fig. 1A and 1C). Microvesicular steatosis, consisting predominantly of swollen, ballooned hepatocytes, with occasional foci of inflammatory cells in the hepatic lobules was observed in the 4-week model group (group C) (Fig. 1B). In the 12-week model group (group D), we observed mild to severe macro- and micro-vesicular steatosis as well as infiltration of mild lobular mixed polymorphonuclear and mononuclear cells. The 12week group also exhibited focal necrosis, perisinusoidal and portal fibrosis, as well as severe hepatocellular ballooning (Fig. 1D). Furthermore, at the end of 4 or 12 weeks, the liver TG level and liver index (liver weight/body weight) were significantly higher than those in controls. Body weight, serum transaminase levels (ALT, AST) and lipids (TG, TC) were also 
Table 1. Serum and liver biochemistry. All data are expressed as the mean \pm standard deviation; Control: the normal control animals fed a standard diet; Model: the model animals fed a HFD; 4W: 4 weeks; $12 \mathrm{~W}: 12$ weeks; ${ }^{*} P<0.05$ vs. control; ${ }^{* *} P<0.01$ vs. control

\begin{tabular}{crrrr}
\hline group & Control-4W & Model-4W & Control-12W & Model-12W \\
\hline items & & & & \\
\hline Weight (g) & $323.80 \pm 25.45$ & $350.8 \pm 36.09$ & $443.1 \pm 33.41$ & $479 \pm 37.98^{*}$ \\
Liver index (\%) & $2.32 \pm 0.26$ & $3.18 \pm 0.18^{* *}$ & $2.53 \pm 0.17$ & $3.45 \pm 0.30^{* *}$ \\
ALT (U/L) & $37.20 \pm 3.71$ & $38.80 \pm 6.91$ & $37.30 \pm 6.00$ & $70.60 \pm 23.30 *$ \\
AST (U/L) & $118.40 \pm 18.51$ & $127.40 \pm 22.81$ & $131.70 \pm 19.34$ & $163.60 \pm 41.58 *$ \\
TG (mmol/L) & $0.58 \pm 0.11$ & $0.60 \pm 0.15$ & $0.80 \pm 0.17$ & $1.08 \pm 0.21^{*}$ \\
TC (mmol/L) & $1.09 \pm 0.12$ & $1.31 \pm 0.18 *$ & $1.47 \pm 0.28$ & $1.96 \pm 0.34^{*}$ \\
Hepatic TG (mmol/g protein) & $130.83 \pm 24.77$ & $411.12 \pm 44.01^{* *}$ & $161.05 \pm 34.01$ & $314.05 \pm 32.68^{* *}$ \\
\hline
\end{tabular}

Fig. 1. High-fat feeding induces hepatic steatosis and steatohepatitis. (A): Rats fed a standard diet for 4 weeks. Normal liver without vacuolar degeneration and no distinct inflammatory cell infiltration as detected by H\&E staining (image magnification: $\times 200$ ). (B): Rats fed a HFD for 4 weeks. Pronounced microvesicular steatosis and predominantly swollen, ballooned hepatocytes with occasional foci of inflammatory cells in the hepatic lobules, as detected by H\&E staining (image magnification: $\times 200$ ). (C): Rats fed a standard diet
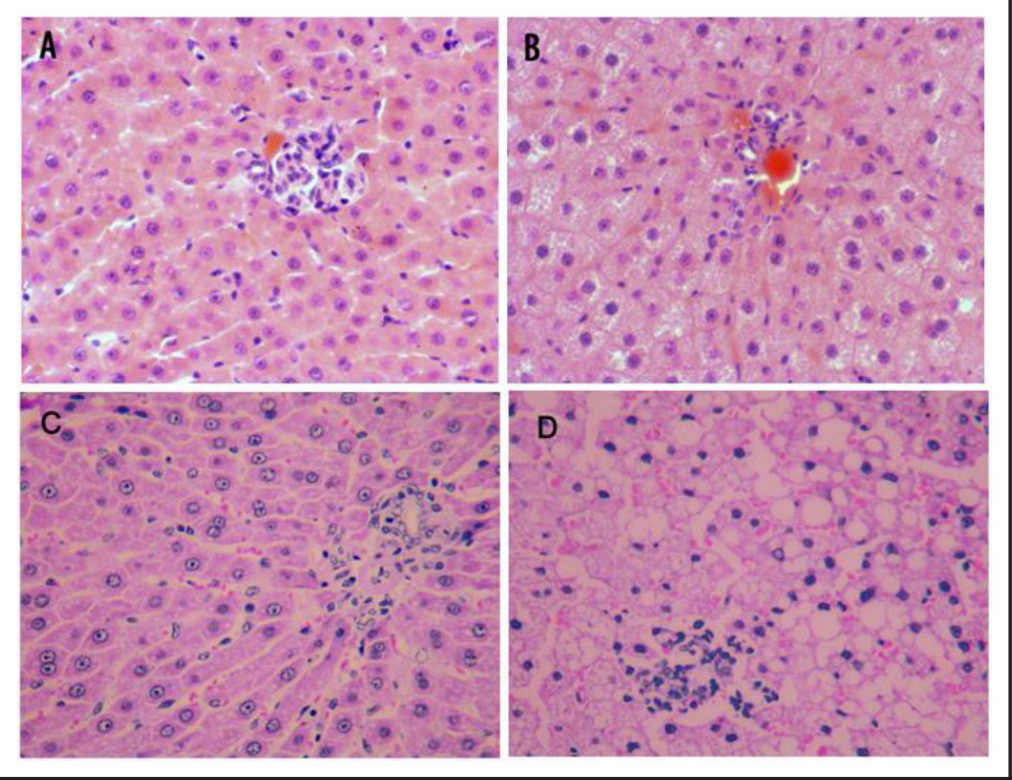
for 12 weeks. Mild microvesicular steatosis without inflammatory infiltration or fibrosis, as detected by H\&E staining (image magnification: $\times 200$ ). (D): Rats fed a HFD for 12 weeks. Pronounced steatohepatitis with some hepatocytes showing severe ballooning, degeneration and foci of inflammatory cell infiltration in the hepatic lobules, as detected by H\&E staining (image magnification: $\times 200$ ).

remarkably elevated in the model group D compared with the control and model C groups (Table 1).

\section{Deep sequencing revealed unique liver miRNA expression profiles}

Deep sequencing has been used to profile miRNA profiles in several species, including plants, animals and humans [29-31]. Although the expression profile of miRNAs in rats and humans with NAFLD has been previously reported [32, 33], we applied Illumina HiSeq deep sequencing to study microRNA expression levels. Briefly, this technique providesa quantitative measure of the presence and prevalence of transcripts from known and previously unknown genes. In total, the two libraries contained 49,478,704 reads, representing 1,665,677 unique sequences (Fig. 2). We focused our analysis on the 33,870,904 reads that matched the mouse genome with $100 \%$ identity over their entire length. The analysis showed that $57.1 \%(11,689,671)$ of all reads from the control library and $50 \%(14,476,560)$ of all reads from the model library matched the annotated miRNA hairpins. Meanwhile, 53 unannotated 


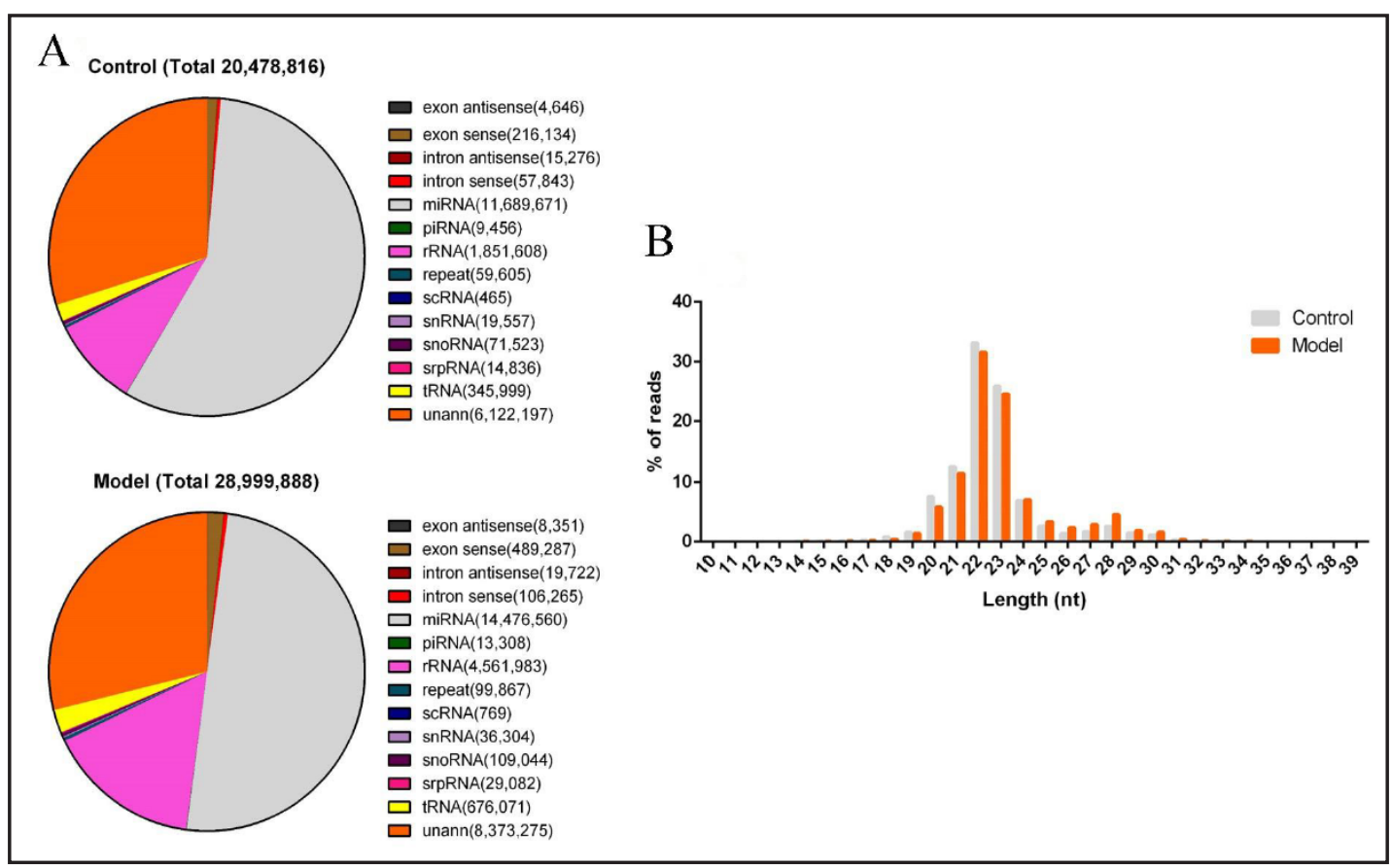

Fig. 2. Quality control of small RNA deep sequencing. (A): Small RNA annotation of the total reads. The above pie chart displays the composition and proportion of small RNAs, with a total of 20,478,816 reads in the control group. The lower chart contains the $28,999,888$ reads for NAFLD model group. (B): Length distribution of deep sequencing results. This figure shows the percent frequency of different length clean reads in each group.

Fig. 3. Scatter plot of all miRNAs by deep sequencing. Comparison of known miRNA expression between the two groups to identify differentially expressed miRNAs. The X-axis and Y-axis show the expression levels of miRNAs in the control and NAFLD samples, respectively. Each point in the figure represents one miRNA.

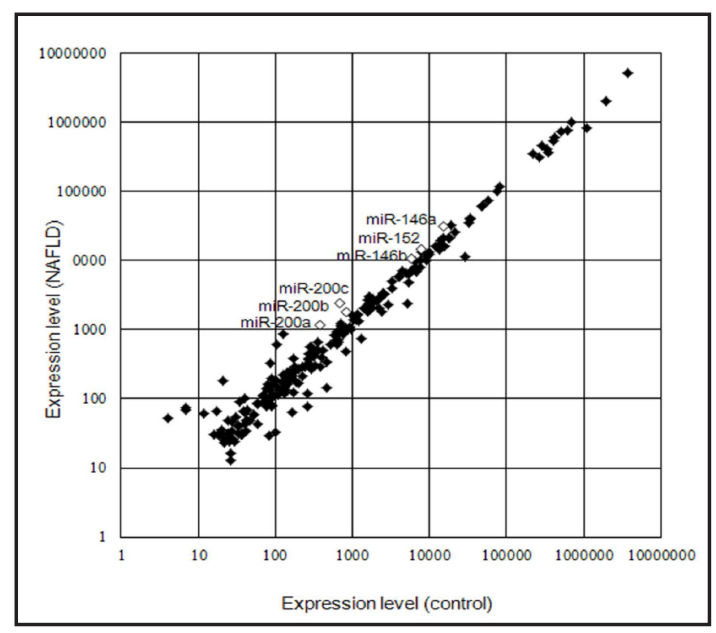

reads from the control and 64 unannotated reads from the model library were previously uncharacterised RNAs, referred to as "novel" sequences (data not shown).

When matching the miRBase 16.0, 239 mature miRNAs were identified in both the control and model groups (Fig. 3). Among these known miRNAs, 44 miRNAs were upregulated and 12 were down-regulated in the model group compared with the control group (Table 2). Although our sequencing results showed that the expression levels of miR-146b and miR-152 in the model group were not 2-fold higher than those in the control group, a recent study indicated that miR-146a and miR-146b regulate the inflammatory response [34]. In addition, miR-152 was found to be up-regulated in many metabolic disorders, such as type 1 diabetes [35]. Thus, we selected miR-200a, miR-200b, miR-200c, miR-146a, miR$146 \mathrm{~b}$ and miR-152 for further analysis. 


\begin{tabular}{|c|c|c|}
\hline \multirow{2}{*}{$\begin{array}{l}\text { Cellular Physiolosy } \\
\text { and Biochemistry }\end{array}$} & \multirow{2}{*}{\multicolumn{2}{|c|}{$\begin{array}{l}\text { Cell Physiol Biochem 2014;34:1983-1997 } \\
\begin{array}{l|l}\text { DOI: 10.1159/000366394 } & \text { 2014 S. Karger AG, Basel }\end{array}\end{array}$}} \\
\hline & & $\begin{array}{l}\text { O } 2014 \text { S. Karger AG, Basel } \\
\text { www.karger.com/cpb }\end{array}$ \\
\hline
\end{tabular}

Table 2. The dysregulated miRNAs in NAFLD, as determined by deep sequencing. The miRNA fold change presented here represents the mean value of sequenced samples from the two groups. "Control" represents the normal 12-week liver group, and "Model" represents the model 12-week liver group. Bold text indicates a change $>1.5$; Italicised text indicates a change $<0.5$

\begin{tabular}{llll}
\hline miRNA & $\begin{array}{l}\text { Fold change } \\
\text { Control vs. Model }\end{array}$ & miRNA & $\begin{array}{l}\text { Fold change } \\
\text { Control vs. Model }\end{array}$ \\
\hline rno-miR-880 & 8.52 & rno-miR-199a-5p & 1.67 \\
rno-miR-881 & 6.97 & rno-miR-148b-3p & 1.66 \\
rno-miR-741-3p & 5.88 & rno-miR-320 & 1.63 \\
rno-miR-200b* & 3.85 & rno-miR-181a-1* & 1.60 \\
rno-miR-200b & 3.54 & rno-miR-339-5p & 1.60 \\
rno-miR-200a & 3.07 & rno-miR-30d & 1.60 \\
rno-miR-141 & 2.50 & rno-miR-503* & 1.60 \\
rno-miR-429 & 2.28 & rno-miR-185 & 1.60 \\
rno-miR-455 & 2.18 & rno-let-7f & 1.57 \\
rno-miR-200c & 2.17 & rno-miR-338 & 1.57 \\
rno-miR-146a & 2.04 & rno-miR-34c & 1.56 \\
rno-miR-499 & 2.03 & rno-miR-142-3p & 1.55 \\
rno-miR-150 & 2.00 & rno-miR-221 & 1.54 \\
rno-miR-29b-1* & 1.94 & rno-miR-186 & 1.53 \\
rno-miR-221* & 1.91 & rno-miR-374 & 1.52 \\
rno-miR-9 & 1.89 & rno-miR-210 & 1.51 \\
rno-miR-152 & 1.87 & rno-miR-671 & 0.43 \\
rno-miR-30c & 1.86 & rno-miR-184 & 0.42 \\
rno-miR-146b & 1.84 & rno-miR-451 & 0.38 \\
rno-miR-322* & 1.82 & rno-miR-501* & 0.35 \\
rno-miR-503 & 1.80 & rno-miR-183 & 0.32 \\
rno-miR-128 & 1.73 & rno-miR-33 & 0.31 \\
rno-miR-342-3p & 1.73 & rno-miR-182 & 0.27 \\
rno-miR-181c & 1.73 & rno-miR-206 & 0.26 \\
rno-miR-30c-2* & 1.71 & rno-miR-144 & 0.24 \\
rno-miR-30b-5p & 1.69 & rno-miR-143* & 0.22 \\
rno-miR-142-5p & 1.69 & rno-miR-1 & 0.22 \\
rno-miR-103 & 1.69 & rno-miR-96 & 0.20 \\
\hline
\end{tabular}

Fig. 4. Validation of the differentially expressed miRNAs in NAFLD. miR-200a, miR-200b, miR-200c, miR-146a, miR-146b and miR-152 were chosen to evaluate the NAFLD models using real-time PCR. (A): The relative expression levels of the six chosen miRNAs in rats fed a HFD for 12 weeks were strikingly greater than those in the control group fed the standard diet for 12 weeks $(n=10)$. (B): Except for miR-200c and miR-146a, the expression levels of the miRNAs in rats fed a HFD for 4 weeks were significantly increased over the control group $(n=10)$. The data are expressed as the mean \pm standard deviation, ${ }^{*} P<0.05$.

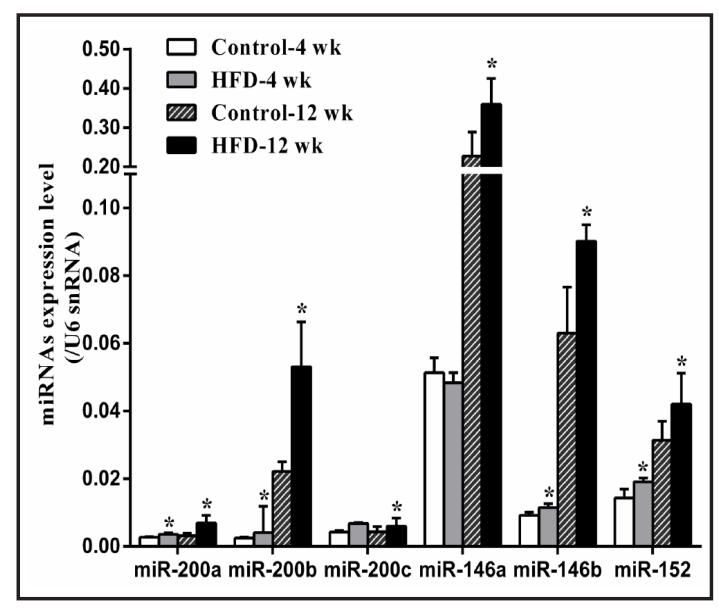

Differential miRNA expression in HFD-induced fatty liver

Stem-loop real-time PCR was used to confirm the deep sequencing results in six randomly selected samples from normal group B and model group D. All of the six chosen miRNAs showed the same expression patterns as observed in the sequencing experiments, further supporting the effectiveness of deep sequencing for screening dysregulated miRNAs (Fig. 4A). To detect miRNA expression in different stages of NAFLD, we also detected the expression of the six miRNAs in 4-week liver samples (Fig. 4B). Four of the selected miRNAs (miR-200a, miR-200b, miR-146b and miR-152) were overexpressed in the model group $(P<0.05)$, whereas two were not (miR-200c, miR-146b). To address the role of miRNAs in NAFLD, we further examined miRNA expression in HepG2 cells and human hepatocytes cultured in complete medium with or without $1 \mathrm{mM}$ of FFA mixture (oleate/palmitate) for 24 h. HepG2 cells (Fig. 5A and 5D) and human hepatocytes (Fig. 5B and 5E) exposed to the FFA mixture developed lipid droplet accumulation. Consistent with this finding, the hepatic 


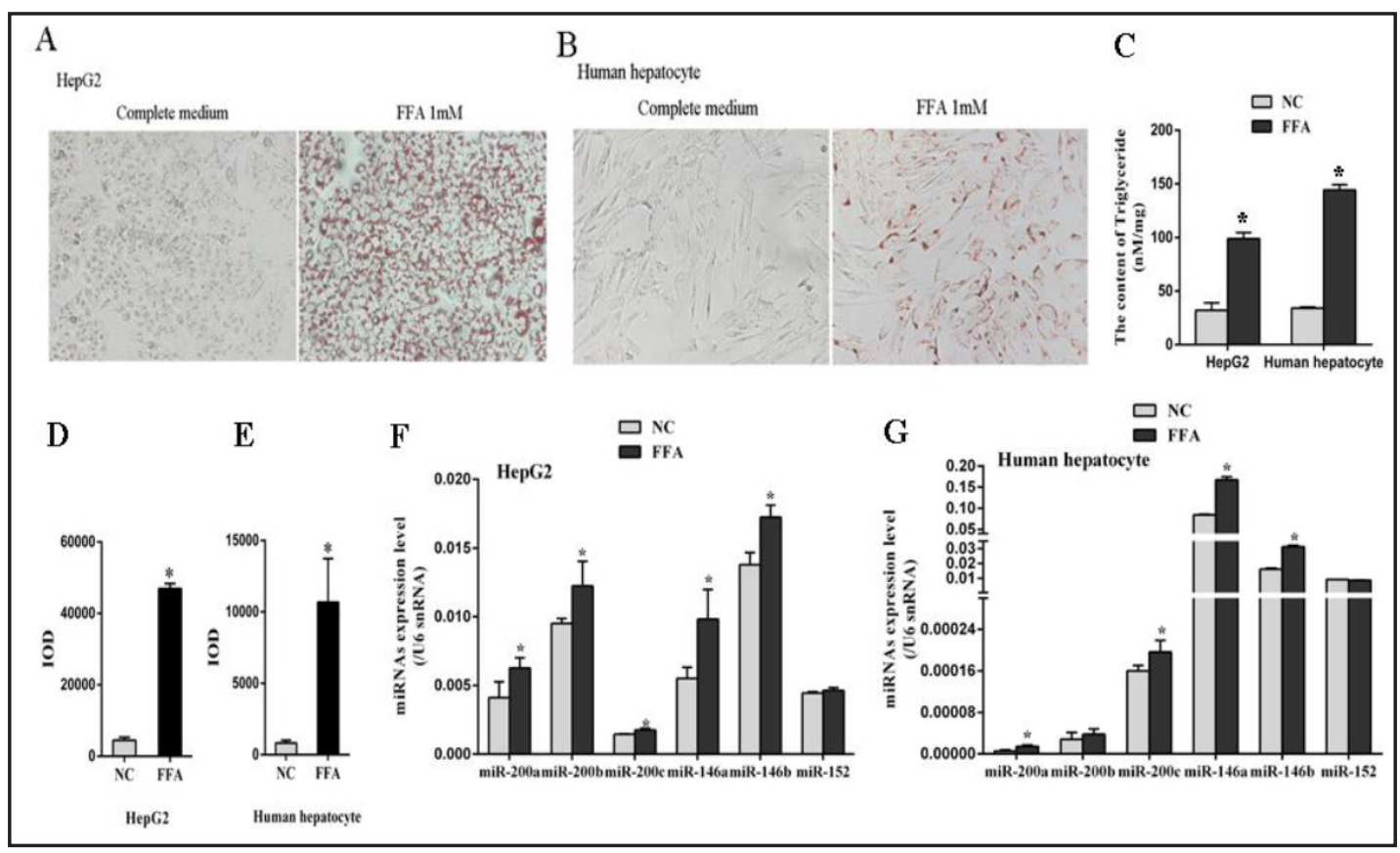

Fig. 5. Lipid accumulation test using HepG2 cells and human hepatocytes. (A, B) Representative Oil Red O staining. (C) The TG content in HepG2 cells and human hepatocytes. (D, E)Integrated option density (IOD) determined by Image Pro-Plus according to the staining intensity by visual assessment. (F, G) The expression levels of the six miRNAs in HepG2 cells cultured in medium with the FFA mixture (1 mM) (C) and human hepatocytes (D). ${ }^{*} P<0.05$.

Fig. 6. The miRNA expression in HepG2 cells cultured with the FFA mixture and TNF- $\alpha$ or IL- 6 for $24 \mathrm{~h}$. The data are expressed as the mean \pm standard deviation, * $P<0.05$ vs. 0 h. (Experiments performed 3 times) (A): $10 \mathrm{ng} / \mathrm{ml} \mathrm{TNF-} \alpha$ treated HepG2 cells for 0, 4, 8, and $24 \mathrm{~h}$. (B): $25 \mathrm{ng} / \mathrm{ml} \mathrm{IL-6}$ treatment led to increased expression of the six miRNAs at $8 \mathrm{~h}$ and $24 \mathrm{~h}$, compared with $0 \mathrm{~h}$.

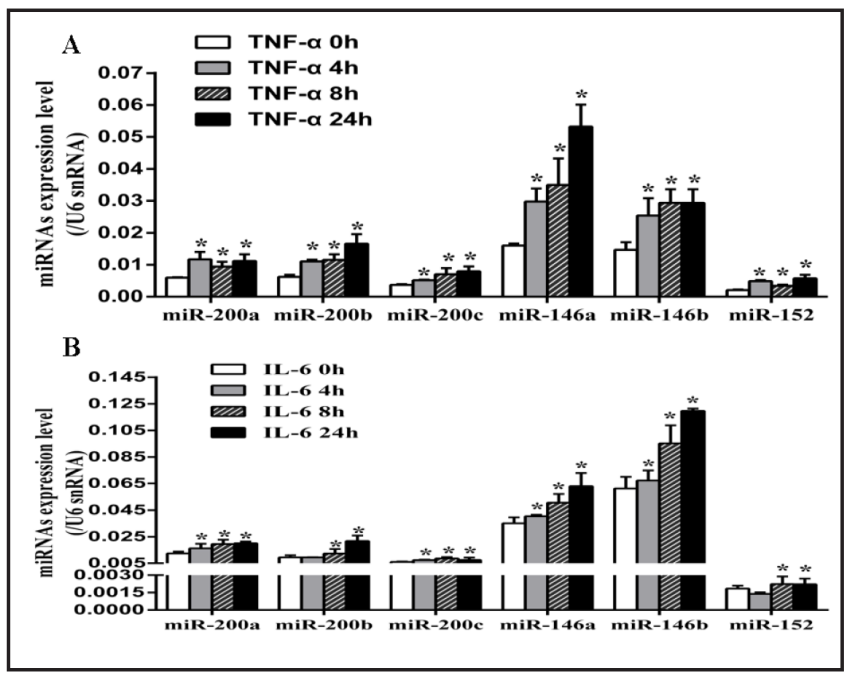

TG content was significantly higher in cells treated with the FFA mixture (Fig. 5C). The expression of certain miRNAs was also increased in fat-overloaded HepG2 cells and human hepatocytes (Fig. 5F and 5G).

The effect of proinflammatory factors on miRNA expression

As both TNF- $\alpha$ and IL-6 play important roles in NAFLD [20,36-38], we assessed whether these proinflammatory factors could alter miRNA expression. HepG2 cells were cultured for $24 \mathrm{~h}$ in complete medium containing FFAs and then cultured for an additional $24 \mathrm{~h}$ with the proinflammatory factors TNF- $\alpha$ (10 ng/ml) [21] and IL-6 $(25 \mathrm{ng} / \mathrm{ml})$ [22]. The cells were collected after $0,4,8$, and $24 \mathrm{~h}$ to determine the expression levels of the six selected miRNAs. 


\begin{tabular}{|c|c|c|}
\hline \multirow{2}{*}{$\begin{array}{l}\text { Cellular Physiolosy } \\
\text { and Biochemistry }\end{array}$} & \multirow{2}{*}{\multicolumn{2}{|c|}{ 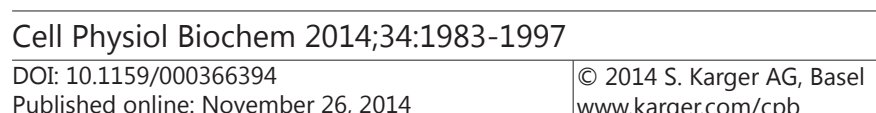 }} \\
\hline & & $\begin{array}{l}\text { O } 2014 \text { S. Karger AG, Basel } \\
\text { www.karger.com/cpb }\end{array}$ \\
\hline
\end{tabular}

Fig. 7. Significant miRNA targets by GO analysis. The GOs targeted by upregulated miRNAs. The GOs targeted by down-regulated miRNAs. All of these GOs show increased enrichment. The vertical axis is the GO category, and the horizontal axis is the enrichment of GO.

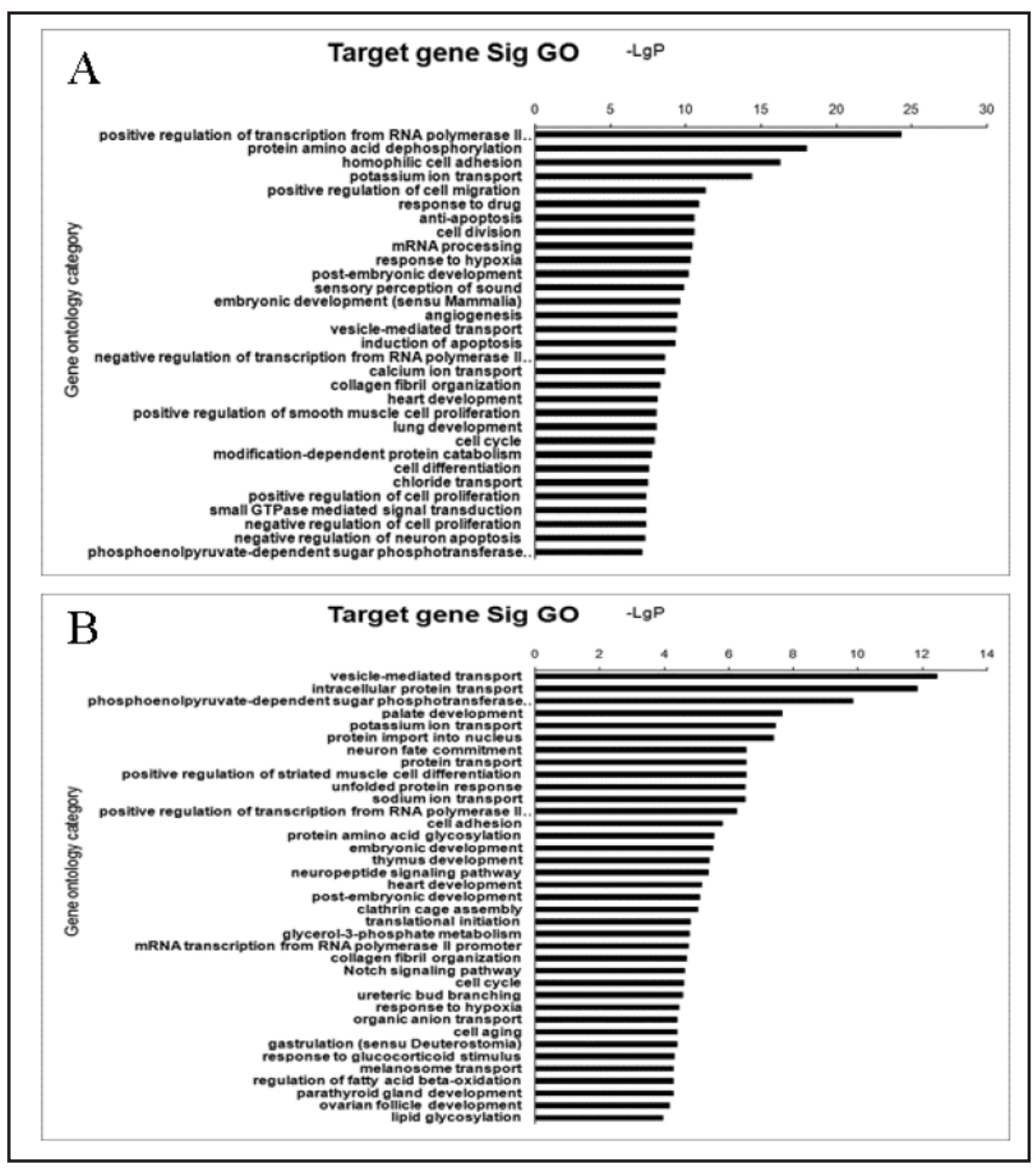

Increased expression levels of the six miRNA were observed in HepG2 cells after treatment with TNF- $\alpha$ and IL-6 (Fig. 6).

\section{GO and KEGG pathway analysis}

Predicted gene targets of all differentially expressed miRNAs were obtained using two databases: TargetScan and miRanda. A total of 2,821 target genes of the up-regulated miRNAs and 507 target genes of the down-regulated miRNAs were identified. All of the predicted targets were categorised into different functional classes, which were identified using gene ontology. In our survey of existing data, the target gene function of up-regulated miRNAs mainly involved the following processes: (1) G0:0045944 - positive regulation of transcription from RNA polymerase II promoter; (2) GO:0006470 - protein amino acid dephosphorylation; (3) G0:0007156 - homophilic cell adhesion; (4) GO:0006813 - potassium ion transport; (5) G0:0030335 - positive regulation of cell migration; and (6) G0:0042493 - response to drug. Meanwhile, the target gene function of down-regulated miRNAs mainly involved the following processes: (1) GO:0016192 - vesicle-mediated transport; (2) GO:0006886 intracellular protein transport; (3) G0:0009401 - phosphoenolpyruvate-dependent sugar phosphotransferase system; (4) GO:0060021 - palate development; (5) G0:0006813 potassium ion transport; and (6) G0:0006606 - protein import into the nucleus (Fig. 7). GO enrichment analysis showed that the mRNA clusters were significantly enriched in basal biological processes, such as material transport, differentiation and development of tissues and organs, and transcriptional regulation.

We also utilised KEGG pathway analysis to address higher-level functions associated with organism behaviours and cellular processes from our sequencing data. In our 
Fig. 8. Pathway analysis based on miRNA target genes. Significant pathways targeted by up-regulated $(\mathrm{A})$ and down-regulated (B) miRNAs. The vertical axis is the pathway category, and the horizontal axis is the pathway enrichment.

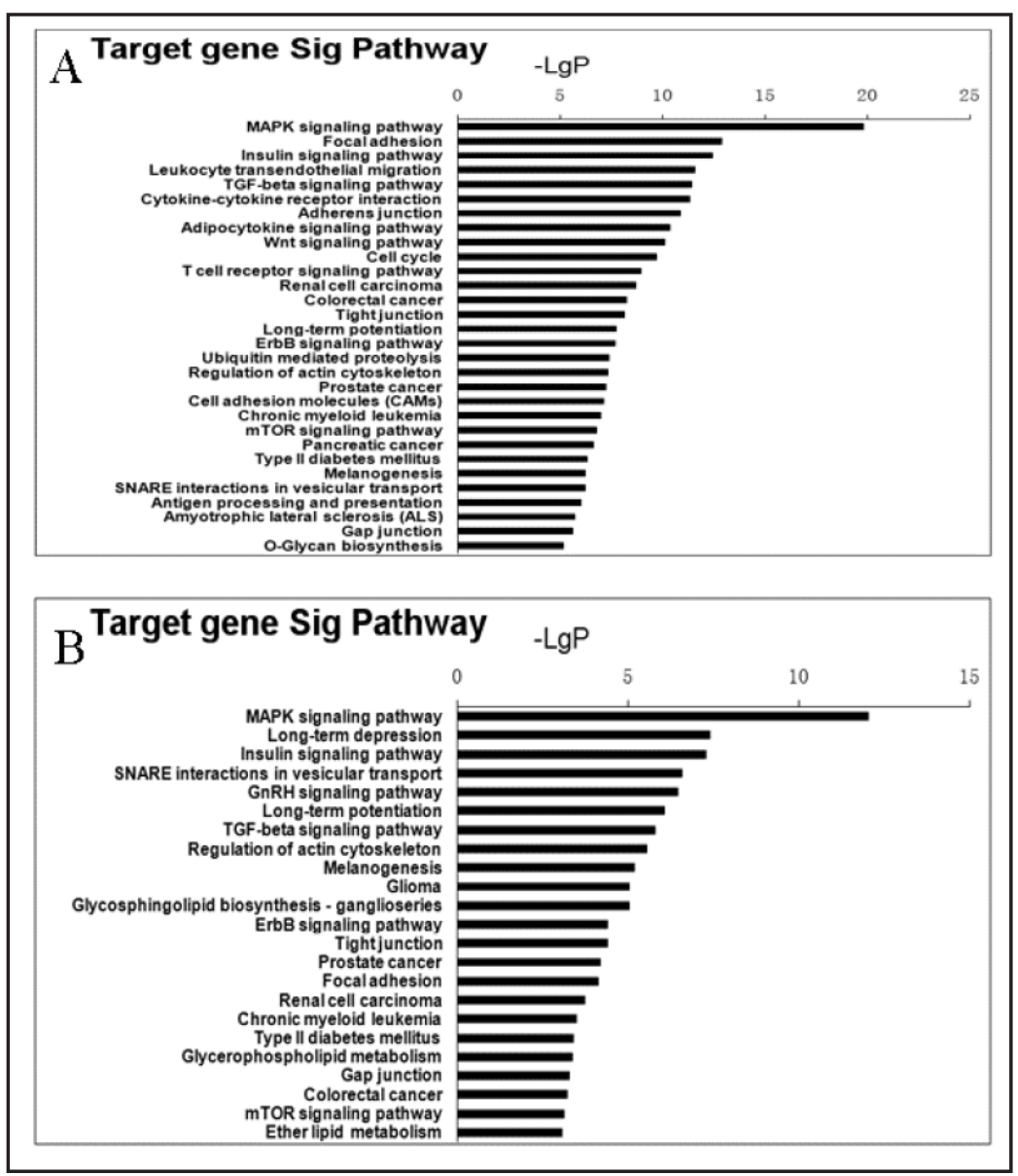

survey of existing data, the target gene function of up-regulated miRNAs mainly involved the following functions: (1) MAPK signalling, (2) focal adhesion signalling, (3) insulin signalling, (4) leukocyte transendothelial migration, (5) TGF-beta signalling, (6) cytokinecytokine receptor interactions, (7) adherens junction adipocytokine signalling, and (8) Wnt signalling. Meanwhile, the target gene function of down-regulated miRNAs mainly involved the following functions: (1) MAPK signalling, (2) long-term depression, (3) insulin signalling, (4) SNARE interactions in vesicular transport, (5) gonadotropin-releasing hormone (GnRH) signalling, (6) long-term potentiation, (7) TGF-beta signalling, and (8) regulation of the actin cytoskeleton (Fig. 8). The significant enrichment of pathways associated with insulin signalling and TGF- $\beta$ signalling indicated that genes with functions potentially relevant to the pathogenesis of NAFLD are targeted by the detected miRNAs [39]. Furthermore, target genes of the up-regulated miRNAs were found to be involved in cytokine-cytokine receptor interactions and the adipocytokine signalling pathway (Fig. 8). Taken together, this information demonstrates that the up-regulated and down-regulated miRNAs co-regulate genes involved in the pathogenesis of NAFLD.

\section{Discussion}

NAFLD is a multifactorial disease that is predominantly regulated by genetic predisposition coupled with environmental factors [40]. Insulin resistance and abnormal lipid metabolism have been accepted as the main driving force behind this disease process. Additionally, inflammation, apoptosis and oxidative stress all play critical roles in NAFLD. The growing application of high-throughput technology has brought miRNAs into focus as potentially important mediators of NAFLD. 
There are several animal models of NAFLD, each with advantages and disadvantages [41]. Here, we adopted a commonly used nutritional model, which utilises a high-fat and high-cholesterol diet to induce fatty liver disease. Using this model, our animals developed visceral obesity and hyperlipidaemia after 4 weeks with high-fat feeding, in addition to hepatic steatosis as detected by liver histology. At the end of 12 weeks, the rats showed an abnormal hepatic enzyme spectrum, and histological analysis revealed the presence of hepatitis. All of the above data indicate that we were able to use a HFD to create a NASH model that reflects the major features of human NAFLD.

To identify the miRNA expression profile of NAFLD, we employed miRNA deep sequencing and validated selected, aberrantly expressed miRNAs by stem-loop RT-PCR. Compared to microarray platforms, the data obtained by deep sequencing is more precise and sensitive [42]. Furthermore, deep sequencing allows the prediction of novel miRNAs using bioinformatic algorithms; in this regard, we predicted more than 100 novel miRNAs that require further experimental verification (data not shown). Overall, there were 44 upregulated miRNAs and 12 down-regulated miRNAs. Within the up-regulated group, the miR200 family was the most notable. Interestingly, each member in this family, including miR200a, miR-200a*, miR-200b, miR-200b*, miR-200c, miR-141 and miR-429, was significantly up-regulated in the NAFLD group. This finding is partially consistent with the characteristics of NAFLD previously observed in diet-induced Sprague-Dawley rats [43], ob/ob mice [43], methyl-deficient mice [44], and NASH patients [33]. In the report by Jin et al., miR-200b expression was increased in the early stages of NAFLD but was decreased in the inflammatory stage of disease [32]. In addition, miR-146 miRNAs (miR146a and miR-146b), first identified as immune system regulators, were also up-regulated [45]. In agreement with this result, miR-146b was reported to be overexpressed in humans with NASH [33]. However, three upregulated miRNAs in our study (miR-880, miR-881 and miR-741-3p) were not previously reported. For the down-regulated group, miR-182 and miR-183 have been reported to exhibit decreased expression in rodents with alcoholic steatohepatitis and increased expression in mice fed a methionine choline-deficient diet [46]; these differences may be attributed to the different models of NASH. Another down-regulated miRNA, miR-451, was also shown to be decreased in diet-induced NAFLD [43], as well as in ob/ob mice [44]. Consequently, miR$200 \mathrm{a} / \mathrm{b} / \mathrm{c}, \mathrm{miR}-146 \mathrm{a} / \mathrm{b}$, and miR-152 were chosen for further validation, and our validation experiment using the animal model of NASH revealed that the expression levels of the six miRNAs were increased during disease development. Our data also demonstrated that these selected miRNAs regulate the gene expression profile involved in NAFLD.

TNF- $\alpha$ and IL- 6 are produced by various cell types, including monocytes/macrophages, T cells, fibroblasts, and endothelial cells. TNF- $\alpha$ and IL- 6 are also secreted by adipocytes and are therefore referred to as adipokines [47]. In particular, TNF- $\alpha$ is a key factor in the development of NAFLD because it can induce inflammation and insulin resistance by activating proinflammatory pathways, such as the NF- $\kappa B$ and $c$-jun $\mathrm{N}$-terminal kinase pathways [36]. An elevated TNF- $\alpha$ level has also been demonstrated in several studies of fatty liver disease [20]. The role of IL-6 in liver pathology is complex, although it has been associated with protection from steatosis via gp130 signalling and activation of the Jak/ Stat pathway in animal models, similar to leptin [37]. Nevertheless, IL-6 is considered a predictive marker of insulin resistance via the induction of SOCS3 expression [48], and serum IL-6 levels are elevated in patients with NAFLD [38]. As such, both TNF- $\alpha$ and IL-6 may be associated with hepatic lipogenesis, obesity and insulin resistance, supporting a central role for these inflammatory factors in NAFLD. To determine the effects of these representative proinflammatory factors on miRNA expression, we used them to treat HepG2 cells. Similar to the results obtained from the sequencing results, both TNF- $\alpha$ and IL- 6 upregulated the expression of the six chosen miRNAs. We interpret this result as indicating that proinflammatory factors are key mediators of the changes in miRNA expression in NAFLD.

As TNF- $\alpha$ and IL- 6 were found to mediate the aberrant expression of miRNAs associated with NAFLD, we also analysed the gene mapping and transcription factor binding sites around the differentially expressed miRNAs (Fig. 9). The gene mapping analyses showed that miR- 


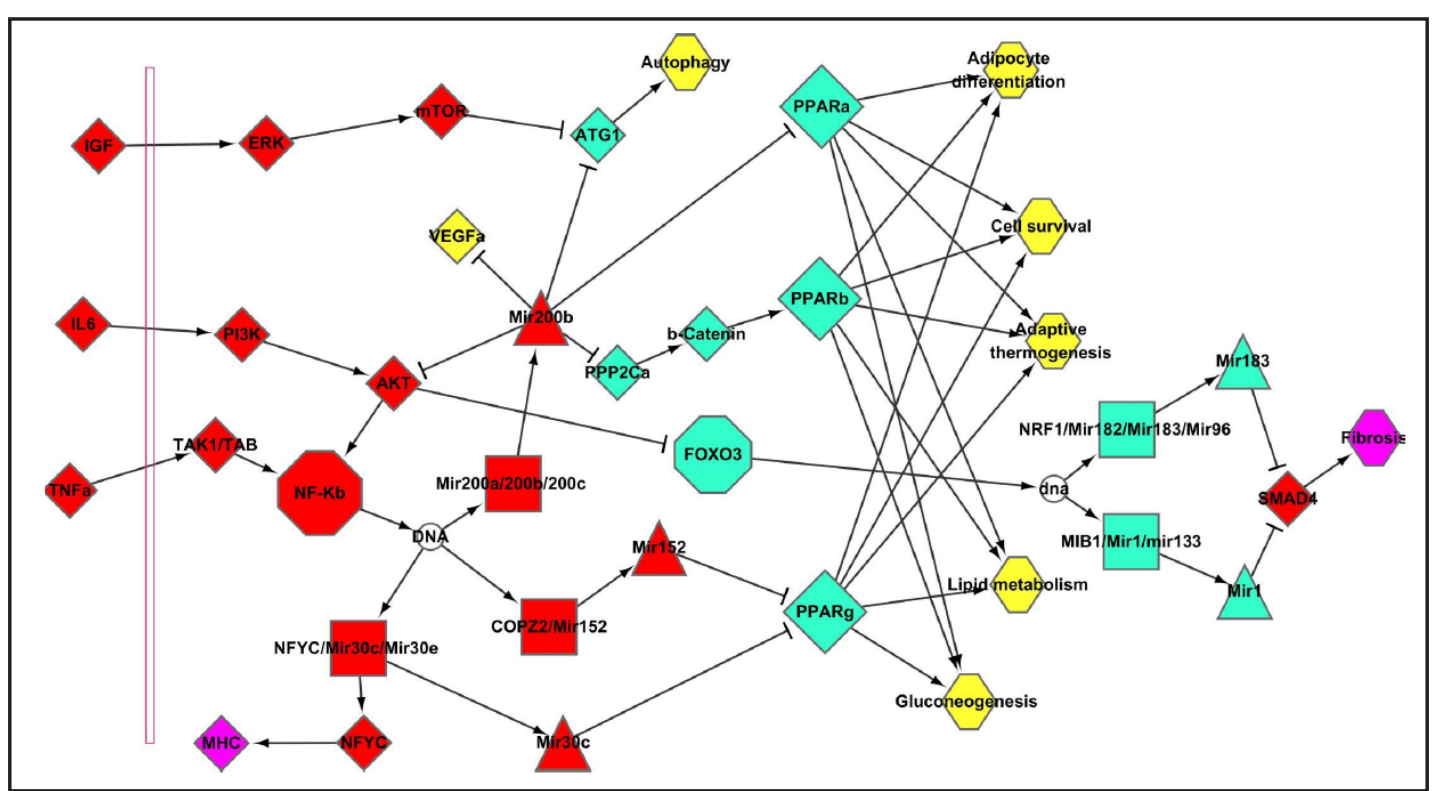

Fig. 9. Potential mechanism for miRNAs associated with NAFLD. The red frames represent up-regulated genes, and the green frames represent down-regulated genes. The yellow boxes represent inhibited biological processes, and the purple boxes represent stimulatory biological process. Two pathways associated with NAFLD were proposed; please refer to the Discussion for details. TNF- $\alpha$ : tumour necrosis factor- $\alpha$; NF- $\kappa B$ : nuclear factor kappa-light-chain-enhancer of activated B cells; PPAR: peroxisome proliferator-activated receptors; ATG: autophagy; PI3K: phosphatidyl inositol 3-kinase; AKT: also known as protein kinase B (PKB); FOX03: Forkhead box 03.

200a, miR-200b and miR-200c have an adjacent genomic location and may be transcribed as a cluster. Alternatively, miR-146a and miR-146b have their own transcriptional regulatory region. We also found that miR-152 is parasitic in the COPZ2 gene, and both function as tumour suppressor genes. Furthermore, miR-30a, miR-30b, and miR-30d share a transcribed region, and miR-30c and miR-30e are both located in the NFYC gene, which encodes MHC I and MHC II molecules. Therefore, these miRNAs are likely to play an important role in antigen presentation. The down-regulated miRNAs, including miR-182, miR-183 and miR-96, are all located in the NRF1 gene, a key gene that mediates oxidative stress. Additionally, miR-1 and miR-133 are both parasitic in the MIB1 gene, which regulates apoptosis [49]. Furthermore, NF- $\kappa$ B can regulate the expression of miR-200b, miR-30c and miR-152 [50-52], whereas miR-182, miR-183, miR-96 and miR-1 can be regulated by FOXO3 [53, 54].

When combining the effect of these two inflammatory factors, two pathways associated with NAFLD were proposed (Fig. 9). In the first pathway, TNF- $\alpha$ stimulates NF- $\kappa B$ activation, which may up-regulate mir-200/mir-30/mir-152 expression, causing abnormal glucose and lipid metabolism/autophagy through targeting PPAR/ATG genes. In the second pathway, IL-6 may activate the PI3K/AKT pathway, thereby down-regulating the expression of the downstream transcription factor FOXO3. This down-regulation would ultimately lead to a lower expression of mir-1/mir-183, causing Smad4 gene expression de-repression and subsequent fibrosis. However, these hypotheses require further experimental evidence.

In summary, this study has shown that NAFLD is associated with changes in the expression of hepatic miRNAs and that the target genes of aberrantly expressed miRNAs are related to the pathogenesis of NAFLD. We also demonstrated that inflammatory factors are crucial mediators of the aberrant expression of miRNAs and propose two pathways leading to the described changes. Although this study was based on a small sample size and included only rodents, we believe that our findings offer novel insights into the pathogenesis of NAFLD in humans. 


\section{Acknowledgments}

This work was supported by grants from the National Natural Science Foundation of China (81270938), Zhejiang Provincial Key Medical Disciplines (Innovation Discipline, 11CX24), Zhejiang Province key scientific and technological innovation team (2010R50050), and the National Key Technology R\&D Program of China (2012BAI02B03).

\section{Disclosure Statement}

The authors declare no conflicts of interest in relation to the content of this article.

\section{References}

1 Chalasani N, Younossi Z, Lavine JE, Diehl AM, Brunt EM, Cusi K, Charlton M, Sanyal AJ:The diagnosis and management of non-alcoholic fatty liver disease: practice Guideline by the American Association for the Study of Liver Diseases, American College of Gastroenterology, and the American Gastroenterological Association. Hepatology 2012;55:2005-2023.

2 Kleiner DE, Brunt EM: Nonalcoholic fatty liver disease: pathologic patterns and biopsy evaluation in clinical research. Semin Liver Dis 2012;32:3-13.

3 Ong JP, Elariny H, Collantes R, Younoszai A, Chandhoke V, Reines HD, Goodman Z, Younossi ZM: Predictors of nonalcoholic steatohepatitis and advanced fibrosis in morbidly obese patients. Obes Surg 2005;15:310315.

4 Widhalm K, Ghods E: Nonalcoholic fatty liver disease: a challenge for pediatricians. Int J Obes (Lond) 2010;34:1451-1467.

-5 Dam-Larsen S, Becker U, Franzmann MB, Larsen K, Christoffersen P, Bendtsen F: Final results of a longterm, clinical follow-up in fatty liver patients. Scand J Gastroenterol 2009;44:1236-1243. Bendtsen F, Dam-Larsen S: Long-term, clinical follow-up in fatty liver patients. Dig Dis 2010;28:709-714. Jones CI, Newbury SF: Functions of microRNAs in Drosophila development. Biochem Soc Trans 2010;38:1137-1143.

8 Chen J, Wang DZ: microRNAs in cardiovascular development. J Mol Cell Cardiol 2012;52:949-957.

9 Jansson MD, Lund AH: MicroRNA and cancer. Mol Oncol 2012;6:590-610.

10 Amiel J, de Pontual L, Henrion-Caude A: miRNA, Development and Disease. Adv Genet 2012;80:1-36.

11 Esau C, Davis S, Murray SF, Yu XX, Pandey SK, Pear M, Watts L, Booten SL, Graham M, McKay R, Subramaniam A, Propp S, Lollo BA, Freier S, Bennett CF, Bhanot S, Monia BP: miR-122 regulation of lipid metabolism revealed by in vivo antisense targeting. Cell Metab 2006;3:87-98.

$\checkmark 12$ Cheung O, Puri P, Eicken C, Contos MJ, Mirshahi F, Maher JW, Kellum JM, Min H, Luketic VA, Sanyal AJ: Nonalcoholic steatohepatitis is associated with altered hepatic MicroRNA expression. Hepatology 2008;48:1810-1820.

13 Zheng L, Lv GC, Sheng J, Yang YD: Effect of miRNA-10b in regulating cellular steatosis level by targeting PPAR-alpha expression, a novel mechanism for the pathogenesis of NAFLD. J Gastroenterol Hepatol 2010;25:156-163.

14 Williams MD, Mitchell GM: MicroRNAs in insulin resistance and obesity. Exp Diabetes Res 2012;2012:484696

15 Li P, Jiao J, Gao G, Prabhakar BS: Control of mitochondrial activity by miRNAs. J Cell Biochem 2012;113:1104-1110.

-16 Tang H, Lee M, Sharpe O, Salamone L, Noonan EJ, Hoang CD, Levine S, Robinson WH, Shrager JB: Oxidative stress-responsive microRNA-320 regulates glycolysis in diverse biological systems. FASEB J 2012;26:47104721.

17 Sen CK, Roy S: MicroRNA 21 in tissue injury and inflammation. Cardiovasc Res 2012;96:230-233.

18 Zeng MD, Fan JG, Lu LG, Li YM, Chen CW, Wang BY, Mao YM: Guidelines for the diagnosis and treatment of nonalcoholic fatty liver diseases. J Digest Dis2008;9:108-112. 
19 Gómez-Lechón MJ, Donato MT, Martínez-Romero A, Jiménez N, Castell J V, O’Connor JE: A human hepatocellular in vitro model to investigate steatosis. Chem-Biol Inter 2007;165:106-116.

20 Coulon S, Francque S, Colle I, Verrijken A, Blomme B, Heindryckx F, De Munter S, Prawitt J, Caron S, Staels B, Van Vlierberghe H, Van Gaal L, Geerts A : Evaluation of inflammatory and angiogenic factors in patients with non-alcoholic fatty liver disease. Cytokine 2012;59:442-449.

-21 Fredriksson L, Herpers B, Benedetti G, Matadin Q, Puigvert JC, de Bont H, Dragovic S, Vermeulen NP, Commandeur JN, Danen E, de Graauw M, van de Water B: Diclofenac inhibits tumor necrosis factoralpha-induced nuclear factor-kappaB activation causing synergistic hepatocyte apoptosis. Hepatology 2010;53:2027-2041.

22 Sun H, Zhang Y, Gao P, Li Q, Sun Y, Zhang J, Xu C: Adiponectin reduces C-reactive protein expression and down-regulates STAT3 phosphorylation induced by IL-6 in HepG2 cells. Mol Cell Biochem 2011;347:183189.

23 Birney E, Stamatoyannopoulos JA, Dutta A, the ENCODE Project Consortium: Identification and analysis of functional elements in 1\% of the human genome by the ENCODE pilot project. Nature 2007;447:799-816.

24 Bammler T, Beyer RP, Bhattacharya S, Boorman GA, Boyles A, Bradford BU, Bumgarner RE, Bushel PR, Chaturvedi K, Choi D, Cunningham ML, Deng S, Dressman HK, Fannin RD, Farin FM, Freedman JH, Fry RC, Harper A, Humble MC, Hurban P, Kavanagh TJ, Kaufmann WK, Kerr KF, Jing L, Lapidus JA, Lasarev MR, Li J, Li YJ, Lobenhofer EK, Lu X, Malek RL, Milton S, Nagalla SR, O’malley JP, Palmer VS, Pattee P, Paules RS, Perou CM, Phillips K, Qin LX, Qiu Y, Quigley SD, Rodland M, Rusyn I, Samson LD, Schwartz DA, Shi Y, Shin JL, Sieber SO, Slifer S, Speer MC, Spencer PS, Sproles DI, Swenberg JA, Suk WA, Sullivan RC, Tian R, Tennant RW, Todd SA, Tucker CJ, Van Houten B, Weis BK, Xuan S, Zarbl H: Standardizing global gene expression analysis between laboratories and across platforms. Nat Methods 2005;2:351-356.

-25 Ewing RM, Chu P, Elisma F, Li H, Taylor P, Climie S, McBroom-Cerajewski L, Robinson MD, O'Connor L, Li M, Taylor R, Dharsee M, Ho Y, Heilbut A, Moore L, Zhang S, Ornatsky O, Bukhman YV, Ethier M, Sheng Y, Vasilescu J, Abu-Farha M, Lambert JP, Duewel HS, Stewart II, Kuehl B, Hogue K, Colwill K, Gladwish K, Muskat B, Kinach R, Adams SL, Moran MF, Morin GB, Topaloglou T, Figeys D: Large-scale mapping of human protein-protein interactions by mass spectrometry. Mol Systems Biol 2007;3:89.

-26 Mukherjee S, Berger MF, Jona G, Wang XS, Muzzey D, Snyder M, Young RA, Bulyk ML: Rapid analysis of the DNA-binding specificities of transcription factors with DNA microarrays. Nat Genet 2004;36:1331-1339.

27 Deutscher D, Meilijson I, Kupiec M, Ruppin E: Multiple knockout analysis of genetic robustness in the yeast metabolic network. Nat Genet 2006;38:993-998.

28 Kanehisa M, Goto S, Furumichi M, Tanabe M, Hirakawa M: KEGG for representation and analysis of molecular networks involving diseases and drugs. Nucleic Acids Res 2010;38:D355-360.

29 Wang K, Li M, Gao F, Li S, Zhu Y, Yang P: Identification of Conserved and Novel microRNAs from Liriodendron chinense Floral Tissues. PLoS One 2012;7:e44696.

- 30 Landgraf P, Rusu M, Sheridan R, Sewer A, Iovino N, Aravin A, Pfeffer S, Rice A, Kamphorst AO, Landthaler M, Lin C, Socci ND, Hermida L, Fulci V, Chiaretti S, Foa R, Schliwka J, Fuchs U, Novosel A, Muller RU, Schermer B, Bissels U, Inman J, Phan Q Chien M, Weir DB, Choksi R, De Vita G, Frezzetti D, Trompeter HI, Hornung V, Teng G, Hartmann G, Palkovits M, Di Lauro R, Wernet P, Macino G, Rogler CE, Nagle JW, Ju J, Papavasiliou FN, Benzing T, Lichter P, Tam W, Brownstein MJ, Bosio A, Borkhardt A, Russo JJ, Sander C, Zavolan M, Tuschl T: A mammalian microRNA expression atlas based on small RNA library sequencing. Cell 2007;129:14011414.

-31 Chiang HR, Schoenfeld LW, Ruby JG, Auyeung VC, Spies N, Baek D, Johnston WK, Russ C, Luo S, Babiarz JE, Blelloch R, Schroth GP, Nusbaum C, Bartel DP: Mammalian microRNAs: experimental evaluation of novel and previously annotated genes. Genes Dev 2010;24:992-1009.

32 Jin X, Ye YF, Chen SH, Yu CH, Liu J, Li YM: MicroRNA expression pattern in different stages of nonalcoholic fatty liver disease. Dig Liver Dis 2009;41:289-297.

33 Cheung O, Puri P, Eicken C, Contos MJ, Mirshahi F, Maher JW, Kellum JM, Min H, Luketic VA, Sanyal AJ: Nonalcoholic steatohepatitis is associated with altered hepatic MicroRNA expression. Hepatology 2008;48:1810-1820.

-34 Taganov KD, Boldin MP, Chang KJ, Baltimore D: NFkappaB-dependent induction of microRNA miR146, an inhibitor targeted to signaling proteins of innate immune responses. Proc Natl Acad Sci USA 2006;103:12481-12486. 


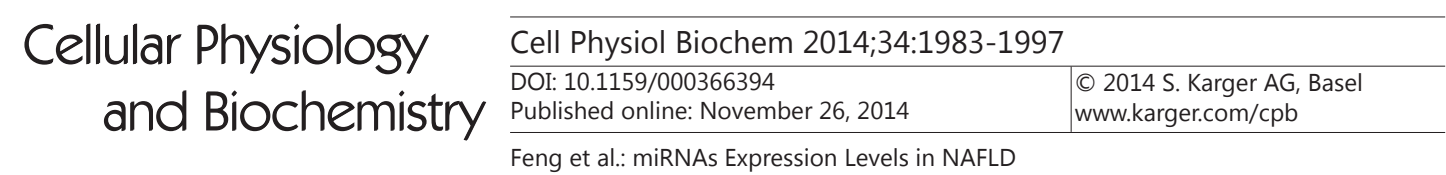

-35 Nielsen LB, Wang C, Sorensen K, Bang-Berthelsen CH, Hansen L,Andersen ML, Hougaard P, Juul A, Zhang CY, Pociot F, Mortensen HB: Circulating levels of microRNA from children with newly diagnosed type 1 diabetes and healthy controls: evidence that miR-25 associates to residual beta-cell function and glycaemic control during disease progression. Exp Diabetes Res 2012;12:896362.

-36 Schenk S, Saberi M, Olefsky JM: Insulin sensitivity: modulation by nutrients and inflammation. J Clin Invest 2008;118:2992-3002.

- 37 Klein C, Wustefeld T, Assmus U, Roskams T, Rose-John S, Muller M, Manns MP, Ernst M, Trautwein C: The IL6-gp130-STAT3 pathway in hepatocytes triggers liver protection in T cell-mediated liver injury. J Clin Invest 2005;115:860-869.

-38 Haukeland JW, Damas JK, Konopski Z, Loberg EM, Haaland T, Goverud I, Torjesen PA, Birkeland K, Bjoro K, Aukrust P: Systemic inflammation in nonalcoholic fatty liver disease is characterized by elevated levels of CCL2. J Hepatol 2006;44:1167-1174.

39 Wilfred DAN, Day CP: Genes and nonalcoholic fatty liver disease. Curr Diab Rep 2008;8:156-163.

40 Day CP: Genetic and environmental susceptibility to non-alcoholic fatty liver disease. Dig Dis 2010;28:255260.

41 Fan JG, Qiao L: Commonly used animal models of non-alcoholic steatohepatitis. Hepatobiliary Pancreat Dis Int 2009;8:233-240.

-42 't Hoen PA, Ariyurek Y, Thygesen HH, Vreugdenhil E, Vossen RH, de Menezes RX, Boer JM, van Ommen GJ, den Dunnen JT: Deep sequencing-based expression analysis shows major advances in robustness, resolution and inter-lab portability over five microarray platforms. Nucleic Acids Res 2008;36:e141.

43 Alisi A, Da SL, Bruscalupi G, Piemonte F, Panera N, De Vito R, Leoni S, Bottazzo GF, Masotti A, Nobili V: Mirnome analysis reveals novel molecular determinants in the pathogenesis of diet-induced nonalcoholic fatty liver disease. Lab Invest 2011;91:283-293.

-44 Pogribny IP, Starlard-Davenport A, Tryndyak VP, Han T, Ross SA, Rusyn I, Beland FA: Difference in expression of hepatic microRNAs miR-29c, miR-34a, miR-155, and miR-200b is associated with strainspecific susceptibility to dietary nonalcoholic steatohepatitis in mice. Lab Invest 2010;90:1437-1446.

45 Taganov KD, Boldin MP, Chang KJ, Baltimore D: NF-kappaB-dependent induction of microRNA miR146, an inhibitor targeted to signaling proteins of innate immune responses. Proc Natl Acad Sci USA 2010;103:12481-12486.

-46 Dolganiuc A, Petrasek J, Kodys K, Catalano D, Mandrekar P, Velayudham A, Szabo G: MicroRNA expression profile in Lieber-DeCarli diet-induced alcoholic and methionine choline deficient diet-induced nonalcoholic steatohepatitis models in mice. Alcohol Clin Exp Res 2009;33:1704-1710.

47 Marra F, Bertolani C: Adipokines in liver diseases. Hepatology 2009;50:957-969.

-48 Senn JJ, Klover PJ, Nowak IA, Zimmers TA, Koniaris LG, Furlanetto RW, Mooney RA: Suppressor of cytokine signaling-3 (SOCS-3), a potential mediator of interleukin-6-dependent insulin resistance in hepatocytes. J Biol Chem 2003;278:13740-13746.

49 Xu C, Lu Y, Pan Z, Chu W, Luo X, Lin H, Xiao J, Shan H, Wang Z, Yang B: The muscle-specific microRNAs miR-1 and miR-133 produce opposing effects on apoptosis by targeting HSP60, HSP70 and caspase-9 in cardiomyocytes. J Cell Sci 2007;120:3045-3052.

-50 Teng Y, Mei Y, Hawthorn L, Cowell JK: WASF3 regulates miR-200 inactivation by ZEB1 through suppression of KISS1 leading to increased invasiveness in breast cancer cells. Oncogene 2014;33:203-211.

-51 Rizzo R, Farina I, Bortolotti D, Baricordi OR, Farina I, Padovan M, Govoni M: Can HLA-G predict disease course in rheumatoid arthritis patients? Int J Clin Rheumatol 2013;8:627-638.

-52 Jiang L, Lin C, Song L, Wu J, Chen B, Ying Z, Fang L, Yan X, He M, Li J, Li M: MicroRNA-30e* promotes human glioma cell invasiveness in an orthotopic xenotransplantation model by disrupting the NF-kappaB/ IkappaBalpha negative feedback loop. J Clin Invest 2012;122:33-47.

53 Mihelich B L, Khramtsova E A, Arva N: miR-183-96-182 cluster is overexpressed in prostate tissue and regulates zinc homeostasis in prostate cells[J]. J Biol Chem 2011;286:44503-44511.

54 Latronico MVG, Condorelli G: microRNAs in hypertrophy and heart failure. Exp Biol Med 2011;236:125131. 